\title{
Pengaruh asupan Fe, vitamin A, vitamin B12, dan vitamin C terhadap kadar hemoglobin pada remaja vegan
}

The effect of iron, vitamin A, vitamin B12, and vitamin C intake on hemoglobin levels in vegetarian adolescents

\author{
Damayanti Siallagan', Prita Dhyani Swamilaksita1, Dudung Angkasa ${ }^{1}$
}

${ }^{1}$ Jurusan Ilmu Gizi, Fakultas Ilmu-ilmu Kesehatan Universitas Esa Unggul

\begin{abstract}
Background: Vegan has become a diet that started to be many people's choice. Low intake of iron and vitamin B12 is factors that can cause anemia in vegan. On the other side vegans often consume vegetables and fruits that contained high of vitamin A and vitamin $C$ which helps the absorption of iron, that can help prevent anemia. Objective: The purpose of the research know the effect of the intake of iron, vitamin A, vitamin B12, vitamin C on hemoglobin (Hb)levels in young Buddhist vegan Pusdiklat Maitreyawira. Method: This research uses cross sectional design. The population in this study are all adolescent vegan in the Buddhist Pusdiklat Maitreyawira. Samples in this study were 31 peoples. Independent variable is an intake of iron, vitamin A, vitamin B12, and vitamin $C$ was obtained by SQ-FFQ, while the dependent variable was $H b$ with hemoglobin testing system quick-check set. Analysis of the data in this study using Pearson correlation and multiple linear regression. Results: There is a relationship intake of iron $(p=0,000)$, vitamin $B 12(p=0,037)$, and vitamin $C(p=0,000)$ to Hb level of adolescent vegan in Buddhist Pusdiklat Maitreyawira, there is no relationship intake of vitamin A with a $\mathrm{Hb}$ level of adolescent vegan $(p=0,220)$. The result of multivariate analysis using multiple regression analysis of the variables that most influence haemoglobin levels of adolescent vegan is the intake of iron and vitamin C. Each increase of $1 \mathrm{mg}$ Fe intake will increase the $\mathrm{Hb}$ concentration as much as $0.013 \mathrm{~g} / \mathrm{dl}$ and increase of $1 \mathrm{mg}$ of vitamin C intake will increase $\mathrm{Hb}$ levels as much as $0.002 \mathrm{~g} / \mathrm{dl}$. Conclusion: Iron and vitamin C intake is the most influence factors to haemoglobin levels of adolescent vegan in Buddhist Pusdiklat Maitreyawira.
\end{abstract}

KEY WORDS: haemoglobin; iron intake; vitamin A intake; vitamin B12 intake; vitamin C intake

\begin{abstract}
ABSTRAK
Latar belakang: Vegetarian telah menjadi pola makan yang mulai banyak menjadi pilihan masyarakat. Rendahnya asupan zat besi dan vitamin B12 merupakan faktor yang dapat menyebabkan anemia pada remaja vegan. Di sisi lain, remaja vegan cenderung memiliki asupan vitamin A dan vitamin C yang tinggi yang berfungsi membantu penyerapan zat besi. Tujuan: Mengetahui pengaruh asupan zat besi, vitamin A, vitamin B12, dan vitamin C terhadap kadar hemoglobin ( $\mathrm{Hb}$ ) pada remaja vegan di Pusdiklat Buddhis Maitreyawira. Metode: Jenis penelitian kuantitatif dengan desain penelitian cross sectional dengan subjek sebanyak 31 remaja vegan. Varibel bebas adalah asupan zat besi, vitamin A, vitamin B12, dan vitamin C yang diperoleh dengan SQ-FFQ, sementara variabel terikat adalah kadar $\mathrm{Hb}$ dengan hemoglobin testing system quik-check set. Analisis data menggunakan uji korelasi Pearson dan uji regresi linier berganda. Hasil: Terdapat hubungan asupan zat besi $(p=0,000)$, asupan vitamin $B 12$ ( $p=0,037)$, dan asupan vitamin $\mathrm{C}(\mathrm{p}=0,000)$ dengan kadar $\mathrm{Hb}$, tetapi tidak ada hubungan asupan vitamin A dengan kadar $\mathrm{Hb}(\mathrm{p}=0,220)$. Asupan zat besi dan asupan vitamin $\mathrm{C}$ merupakan variabel yang paling mempengaruhi kadar $\mathrm{Hb}$ pada remaja vegan. Setiap kenaikan $1 \mathrm{mg}$ asupan Fe akan meningkatkan kadar $\mathrm{Hb}$ remaja vegan sebesar 0,013 g/dl dan setiap penambahan $1 \mathrm{mg}$ asupan vitamin $\mathrm{C}$ akan meningkatkan kadar $\mathrm{Hb}$ remaja vegan sebanyak 0,002 g/dl. Simpulan: Asupan zat besi dan vitamin $\mathrm{C}$ merupakan variabel yang paling mempengaruhi kadar Hb remaja vegan di Pusdiklat Buddhis Maitreyawira.
\end{abstract}

KATA KUNCI: kadar hemoglobin; asupan Fe; asupan vitamin A; asupan vitamin B12; asupan vitamin C

\section{PENDAHULUAN}

Penganut diet vegetarian menunjukkan peningkatan pesat setiap tahunnya. Survei yang diadakan pada tahun 1997 terdapat 1\% penduduk Amerika Serikat yang vegetarian kemudian meningkat menjadi 2,5\% pada tahun 2000 kemudian $2,8 \%$ pada tahun 2003 , dan pada tahun

Korespondensi: Damayanti Siallagan, Jurusan Ilmu Gizi, Fakultas Ilmu-ilmu Kesehatan, Universitas Esa Unggul, Jln. Arjuna Utara No. 9, Kebon Jeruk, Jakarta Barat,e-mail: damayantisiallagan@gmail.com 
2006 diperkirakan telah mencapai 30-40\%. Di Australia, berdasarkan survei yang dilakukan oleh Newspoll pada tahun 2010 dilaporkan bahwa 2\% penduduk Australia adalah vegetarian. Sementara di India pada tahun 2003, $50 \%$ penduduknya adalah vegetarian. Di Indonesia, data dari Indonesia Vegetarian Society (IVS) menunjukkan peningkatan jumlah anggota yang pesat dari 5.000 orang pada tahun 1998, menjadi 60.000 orang pada tahun 2007, dan diprediksi sekitar 500.000 orang pada tahun 2010 (1).

Diet vegetarian berisiko tinggi terhadap kejadian kekurangan beberapa jenis zat gizi seperti protein, asam amino, asam lemak omega 3, omega 6, vitamin D, vitamin B12, kalsium, seng, tembaga, dan besi (2). Risiko kekurangan ini lebih besar terutama pada kelompok vegetarian yang sama sekali tidak mengonsumsi makanan hewani (vegan). Hal ini diperkuat oleh penelitian terhadap asupan gizi vegan yang menunjukkan konsumsi protein, vitamin B12 lebih rendah pada vegan dan asupan besi dan seng hampir dua kalinya (3). Di antara beberapa zat-zat gizi yang berisiko tinggi untuk mengalami defisiensi pada kelompok vegan, memiliki fungsi yang sangat esensial bagi tubuh dalam pembentukan hemoglobin $(\mathrm{Hb})$ seperti protein, besi, dan vitamin B12. Kekurangan zat-zat gizi tersebutlah yang dapat menyebabkan tingginya risiko anemia pada kelompok vegan. Penelitian sebelumnya yang mengkaji tentang vegetarian dilakukan pada wanita usia subur (WUS) vegan menunjukkan bahwa 48,2 \% WUS vegan menderita anemia (4). Meskipun kelompok vegan kekurangan beberapa jenis protein dan asam amino, vitamin B12, dan besi, tetapi makanan yang dikonsumsi kelompok vegan pada umumnya kaya akan vitamin $\mathrm{C}$ dan karoten yang di dalam tubuh akan diubah menjadi vitamin A. Vitamin A di dalam tubuh berperan dalam memobilisasi cadangan besi di dalam tubuh untuk dapat mensintesis $\mathrm{Hb}$, hal ini juga diperkuat dengan hasil penelitian yang menyimpulkan bahwa asupan vitamin A signifikan mempengaruhi kadar $\mathrm{Hb}$ (5). Sementara vitamin C berperan dalam meningkatkan absorpsi zat besi non-heme (6).

Remaja merupakan kelompok yang rentan mengalami anemia karena masa remaja merupakan periode terjadinya pertumbuhan dan perkembangan yang pesat. Berdasarkan data Riset Kesehatan Dasar (Riskesdas) tahun 2013 diketahui bahwa 18,4\% remaja
Indonesia mengalami anemia. Penelitian mengenai hubungan asupan gizi dan kadar $\mathrm{Hb}$ pada kelompok vegetarian terutama remaja vegan masih sangat sedikit. Dengan demikian, penelitian ini perlu dilakukan dengan tujuan untuk mengetahui bagaimana pengaruh asupan zat besi (Fe), vitamin A, vitamin B1, dan vitamin C terhadap kadar $\mathrm{Hb}$ pada remaja vegan di Pusdiklat Buddhis Maitreyawira.

\section{BAHAN DAN METODE}

Penelitian ini dilakukan di Komunitas Pusdiklat Buddhis Maitreyawira pada bulan Mei - Juli 2016. Jenis penelitian ini bersifat observasional analitik dengan desain cross sectional (potong lintang) untuk mengetahui pengaruh asupan zat besi, vitamin A, vitamin B12, dan vitamin $C$ sebagai variabel independen terhadap kadar $\mathrm{Hb}$ sebagai variabel dependen pada remaja vegan. Sampel pada penelitian ini adalah seluruh remaja vegan di Pusdiklat Buddhis Maitreyawira yang berjumlah 31 orang yang sesuai dengan kriteria sampel yang sudah ditentukan. Kriteria untuk pemilihan sampel yaitu remaja vegan di Pusdiklat Buddhis Maitreyawira, berumur 1225 tahun, tidak dalam keadaan sakit, dan sedang tidak mengalami menstruasi.

Data asupan zat besi, vitamin A, vitamin B12, dan vitamin $\mathrm{C}$ dikumpulkan dengan teknik wawancara menggunakan metode semi quantitatif food frequency questionnaire (SQ-FFQ). Selain melihat seberapa besar asupan zat gizi yang dikonsumsi setiap harinya oleh subjek, asupan zat gizi tersebut juga dibandingkan dengan angka kecukupan gizi (AKG) yang kemudian dikategorikan menjadi dua yaitu kurang $(<65 \%$ dari AKG) dan cukup ( $\geq 65 \%$ dari $\mathrm{AKG}$ ). Data kadar $\mathrm{Hb}$ dikumpulkan menggunakan alat digital Hemoglobin Testing System Quick-Check Set. Analisis bivariat dengan uji korelasi Pearson Product Moment dilakukan untuk menganalisis pengaruh asupan zat besi, vitamin A, vitamin B12, dan vitamin C terhadap kadar Hb. Analisis multivariat yang digunakan adalah analisis regresi linier berganda dengan model awal regresi sebagai berikut: Kadar $\mathrm{Hb}: \beta \mathrm{o}+\beta_{1}$ Asupan $\mathrm{Fe}+\beta_{2}$ Asupan Vit $\mathrm{C}+\beta_{3}$ Asupan Vit B12 $+\beta_{4}$ Asupan Vit A. Analisis multivariat dengan uji regresi linier berganda digunakan untuk 
mengetahui variabel independen mana yang paling berpengaruh antara asupan zat gizi $(\mathrm{Fe}$, vitamin $\mathrm{B} 12$ dan vitamin C) terhadap kadar Hb. Sebelum dilakukan analisis multivariat menggunakan uji regresi linier berganda, dilakukan analisis normalitas terlebih dahulu dan analisis asumsi klasik. Analisis normalitas bertujuan untuk melihat apakah nilai residual berdistribusi normal atau tidak sedangkan analisis asumsi klasik dilakukan untuk melihat apakah suatu model bebas dari gejala multikolinieritas dan masalah heteroskedastisitas.

\section{HASIL}

Hasil penelitian menunjukkan bahwa subjek penelitian mayoritas tergolong sebagai remaja akhir yaitu berusia 17-25 tahun sebanyak 24 orang $(77,4 \%)$. Hal ini menunjukkan bahwa remaja yang memutuskan untuk menjadi penganut vegetarian murni sebagian besar tergolong pada remaja akhir (17-25 tahun). Distribusi remaja vegan di Pusdiklat Buddhis Maitreyawira berdasarkan tingkat pendidikannya adalah SMP sebanyak 3 orang $(9,7 \%)$, SMA sebanyak 8 orang $(25,8 \%)$, D3 sebanyak 1 orang $(3,2 \%)$, dan S1 sebanyak 19 orang (61,3\%). Berdasarkan hasil penelitian ini didapatkan bahwa rata-rata remaja vegan di Pusdiklat Buddhis Maitreyawira tidak mengalami anemia (90,3\%) (Tabel 1).

Tabel 2 menunjukkan rerata asupan subjek dan kategori asupan setelah dibandingkan dengan AKG, tampak bahwa sebagian besar asupan Fe tergolong kurang (83,9\%). Bahkan, seluruh subjek penelitian ini memiliki asupan vitamin $\mathrm{B} 12$ dan vitamin $\mathrm{C}$ yang tergolong kurang. Hanya asupan vitamin A subjek yang tergolong cukup sudah memenuhi AKG.

Analisis bivariat untuk mengetahui hubungan antara variabel dependen ( $\mathrm{kadar} \mathrm{Hb}$ ) dan variabel independen ( $\mathrm{Fe}$, vitamin $\mathrm{A}$, vitamin $\mathrm{B} 12$, dan vitamin $\mathrm{C}$ ) menggunakan uji korelasi Pearson. Sebelum dilakukan uji korelasi Pearson, dilakukan uji normalitas data terlebih dahulu menggunakan uji Shapiro-Wilk dengan hasil bahwa distribusi frekuensi setiap variabel adalah normal ( $p>0,05)$. Tabel 3 menunjukkan bahwa asupan zat besi, asupan vitamin B12, dan asupan vitamin C memiliki hubungan yang signifikan dengan kadar $\mathrm{Hb}$ remaja vegan di Pusdiklat Buddhis Mautreyawira
Tabel 1. Distribusi frekuensi berdasarkan karakteristik responden

\begin{tabular}{lcc}
\hline \multicolumn{1}{c}{ Variabel } & n & \% \\
\hline Usia & & \\
Remaja awal & 7 & 22,6 \\
Remaja akhir & 24 & 77,4 \\
Jenis kelamin & & \\
$\quad$ Laki - laki & 10 & 32,3 \\
$\quad$ Perempuan & 21 & 67,7 \\
Pendidikan & & \\
$\quad$ <MA & 3 & 9,7 \\
SMA & 28 & 90,3 \\
Kadar Hb & & \\
Anemia & 3 & 9,7 \\
Tidak anemia & 28 & 90,3 \\
\hline
\end{tabular}

Tabel 2. Distribusi frekuensi responden berdasarkan asupan $\mathrm{Fe}$, vitamin $\mathrm{A}$, vitamin $\mathrm{B} 12$ dan vitamin $\mathrm{C}$

\begin{tabular}{lcc}
\hline \multicolumn{1}{c}{ Asupan } & n (\%) & rerata \pm SD \\
\hline Fe $(\mathrm{g})$ & & \\
Kurang & $26(83,9)$ & $263,51 \pm 73,5$ \\
Cukup & $5(16,1)$ & \\
Vitamin A $(\mu \mathrm{g})$ & & \\
$\quad$ Kurang & $0(0)$ & $41.793,80 \pm 7.063,32$ \\
Cukup & $31(100)$ & \\
Vitamin B12 $(\mathrm{g})$ & & \\
$\quad$ Kurang & $31(100)$ & $3,5 \pm 1,6$ \\
Cukup & $0(0)$ & \\
Vitamin C (g) & & \\
Kurang & $0(0)$ & $2.977,9 \pm 403,9$ \\
Cukup & $31(100)$ & \\
\hline
\end{tabular}

Tabel 3. Hubungan kadar $\mathrm{Hb}$ dengan asupan $\mathrm{Fe}$, vitamin $A$, vitamin B12, dan vitamin C

\begin{tabular}{lcc}
\hline \multicolumn{1}{c}{ Variabel } & $\mathbf{R}$ & $\mathbf{p}$ \\
\hline Asupan zat besi & 0,623 & $0,000^{*}$ \\
Asupan vitamin A & 0,227 & 0,220 \\
Asupan vitamin B12 & 0,377 & $0,037^{*}$ \\
Asupan vitamin C & 0,631 & $0,000^{*}$ \\
\hline
\end{tabular}

*Sigfinikan $(\mathrm{p}<0,05)$

$(\mathrm{p}<0,05)$ sedangkan asupan vitamin A tidak berhubungan signifikan dengan kadar $\mathrm{Hb}$ remaja vegan di Pusdiklat Buddhis Mautreyawira ( $p>0,05)$.

Setelah melalui analisis normalitas dan analisis asumsi klasik diketahui bahwa nilai residual berdistribusi normal $(\mathrm{p}>0,05)$ dan model terbebas dari gejala multikolinieritas (VIF value $>10$ ) dan masalah heterokedastisitas sehingga dapat dilanjutkan untuk 
Tabel. 4. Hasil analisis uji regresi linier berganda

\begin{tabular}{lcccc}
\hline Variabel & B & t & Sig & $\mathbf{9 5 \% C I}$ \\
\hline Asupan Fe & 0,013 & 3,481 & 0,002 & $0,005-0,020$ \\
Asupan vitamin C & 0,002 & 3,160 & 0,004 & $0,001-0,003$ \\
Konstanta & 2,564 & 1,164 \\
\hline F (sig) & \multicolumn{5}{c}{13,839} \\
F square & \multicolumn{5}{c}{0,000} \\
Rar & 0,606 \\
\hline
\end{tabular}

Variabel dependen: kadar $\mathrm{Hb}$

dianalisis menggunakan uji regresi linier berganda. Berdasarkan hasil uji regresi linier berganda (Tabel 4) didapatkan nilai prob. F hitung (sig.) adalah $0,000<$ 0,05 sehingga dapat disimpulkan bahwa model regresi linier yang diestimasi layak untuk digunakan. Koefisien determinasi (R square) diperoleh sebesar 0,606. Hal ini menunjukkan bahwa variasi kadar $\mathrm{Hb} 60,6 \%$ dipengaruhi oleh asupan zat besi dan asupan vitamin C sedangkan sebesar 39,4\% dijelaskan oleh variabel lain yang tidak diteliti. Interval kepercayaan pada batas $95 \%$ CI tidak melewati nilai 1, maka dinyatakan hasil analisis tersebut signifikan. Berdasarkan hasil analisis uji kelayakan ini, dapat disimpulkan bahwa asupan Fe dan asupan vitamin $\mathrm{C}$ signifikan mempengaruhi nilai dari kadar $\mathrm{Hb}$ remaja vegan di Pusdiklat Buddhis Maitreyawira. Persamaan garis linier yang diperoleh yaitu:

$$
\begin{gathered}
\text { Kadar } \mathrm{Hb}=2.564+(0,013 \times \text { asupan } \mathrm{Fe})+(0,002 \times \\
\text { asupan vitamin } \mathrm{C})
\end{gathered}
$$

Dari persamaan tersebut dapat diinterpretasikan bahwa setiap kenaikan $1 \mathrm{mg}$ asupan Fe akan menaikkan kadar $\mathrm{Hb}$ remaja vegan di Pusdiklat Buddhis Maitreyawira sebesar $0,013 \mathrm{~g} / \mathrm{dl}$ serta setiap penambahan $1 \mathrm{mg}$ asupan vitamin $\mathrm{C}$ akan meningkatkan kadar $\mathrm{Hb}$ remaja vegan di Pusdiklat Buddhis Maitreyawira sebanyak 0,002 g/dl.

\section{BAHASAN}

\section{Karakteristik subjek}

Subjek pada penelitian ini adalah remaja vegan (vegetarian murni) umur 12 sampai 25 tahun. Hasil penelitian menunjukkan bahwa dari 31 remaja vegan sebagian besar tergolong pada remaja akhir (17-25 tahun) dan sebagian kecil tergolong remaja awal (12-16 tahun).
Hal ini menunjukkan bahwa remaja yang memutuskan untuk menjadi penganut vegetarian murni sebagian besar tergolong pada remaja akhir. Hasil survei yang dilakukan oleh NDNS UK pada tahun 2010 juga menyatakan bahwa dari seluruh vegetarian yang ada di Inggris hanya 3 persen anak yang berusia 11-18 tahun yang dilaporkan menjadi vegetarian (7). Hal ini sejalan dengan kondisi psikologis remaja awal yang memang masih labil dan masih ingin melakukan hal-hal yang menyenangkan (8). Berdasarkan wawancara dengan para remaja vegetarian di Pusdiklat Buddhis Maitreyawira, para remaja awal banyak yang belum memutuskan menjadi penganut vegetarian murni dikarenakan mereka merasa menjadi vegan merupakan hal yang berat untuk dilakukan dikarenakan mereka tidak boleh sama sekali mengonsumsi makanan sumber hewani.

Lebih lanjut, remaja di Pusdiklat Buddhis Maitreyawira yang memutuskan menjadi vegetarian murni sebagian besar dilatarbelakangi oleh masalah agama. Semua remaja pada penelitian ini beragama Buddha aliran Maitreya yang menganjurkan umatnya untuk menjadi vegetarian murni. Hasil dari penelitian ini menunjukkan bahwa dari 31 remaja vegan di Pusdiklat Buddhis Maitreyawira, sebagian besar berjenis kelamin perempuan. Beradasarkan hasil ini dapat diketahui bahwa rata-rata remaja yang menganut vegetarian murni di Pusdiklat Buddhis Maitreyawira adalah perempuan. Hal ini sejalan dengan survei yang dikumpulkan oleh Pew Research Center tahun 2009 (9), survei menyatakan bahwa perempuan mempunyai hubungan dengan suatu kepercayaan sebesar 86 persen, sementara laki-laki 79 persen. Sebanyak 77 persen perempuan juga memiliki suatu kepercayaan penuh tersendiri akan adanya Tuhan sedangkan pada laki-laki hanya 65 persen. Sementara dalam hal praktik, 66 persen perempuan yang melakukan ibadah sedangkan laki-laki hanya 49 persen.

Distribusi remaja vegan di Pusdiklat Buddhis Maitreyawira berdasarkan tingkat pendidikan menunjukkan bahwa sebagian besar berpendidikan S1 atau sedang menjalani pendidikan S1. Menurut teori (10), pengetahuan sangat erat kaitannya dengan pendidikan. Semakin tinggi pendidikan seseorang, maka semakin luas pula pengetahuannya. Pendidikan mempengaruhi proses belajar, semakin tinggi pendidikan seeorang 
akan semakin mudah untuk menerima informasi karena cenderung lebih banyak mendapatkan informasi, baik dari orang lain maupun dari media massa. Semakin banyak informasi yang masuk, semakin banyak pula pengetahuan yang diperoleh. Hasil penelitian ini sejalan dengan teori yang menyebutkan bahwa para remaja yang memutuskan untuk menjadi vegan (vegetarian murni) di Pusdiklat Buddhis Maitreyawira didominasi oleh remaja yang berpendidikan S1.

\section{Kadar hemoglobin pada remaja vegan}

Berdasarkan hasil penelitian ini diketahui bahwa rata-rata remaja vegan di Pusdiklat Buddhis Maitreyawira tidak mengalami anemia dan hanya sebagian kecil yang anemia. Tiga orang remaja yang mengalami anemia adalah perempuan. Hal ini kemungkinan disebabkan remaja perempuan yang baru saja mengalami menstruasi. Remaja perempuan lebih berisiko menderita anemia daripada remaja laki-laki karena setiap bulan remaja perempuan mengalami menstruasi. Di samping itu, remaja perempuan sering kali menjaga penampilan, ingin kurus sehingga berdiet dan mengurangi makanan apalagi menjadi vegan hanya mengonsumsi makanan sumber nabati yang menyebabkan asupan protein hewani dan zat besi akan lebih rendah dibandingkan remaja yang nonvegan dan nonvegetarian.

\section{Asupan zat besi, vitamin A, C, dan B12 pada remaja vegan}

Hasil penelitian menunjukkan bahwa sebagian besar asupan harian zat besi remaja vegan di Pusdiklat Buddhis Maitreyawira tergolong kurang $(<65 \%$ dari AKG). Hanya sebagian kecil (16,13\%) yang asupan zat besinya tergolong cukup. Hal ini terjadi karena pada remaja vegan hanya mengonsumsi makanan yang bersumber dari bahan makanan nabati, sementara bahan makanan nabati pada umumnya rendah akan zat besi. Demikian pula dengan asupan harian vitamin B12 pada seluruh remaja vegan yang tergolong kurang $(<65 \%$ dari AKG). Seperti yang telah dijelaskan di atas bahwa remaja vegan hanya mengonsumsi makanan yang bersumber dari bahan makanan nabati, sementara sumber bahan makanan nabati yang mengandung vitamin B12 hanyalah tempe sehingga remaja vegan akan sangat sulit untuk bisa memenuhi kebutuhan vitamin B12. Hal ini sejalan dengan penelitian pada kelompok vegan di Inggris (11) yang menyatakan bahwa asupan vitamin B12 lebih rendah jika dibandingkan dengan kelompok nonvegan.

Lebih lanjut, diketahui bahwa asupan harian vitamin A seluruh remaja vegan yang menjadi subjek penelitian ini tergolong cukup ( $>65 \%$ dari AKG). Asupan vitamin A yang cukup ini karena remaja vegan banyak mengonsumsi makanan yang kaya akan vitamin A. Berdasarkan hasil wawancara dengan SQ-FFQ, diketahui bahwa bahan makanan sumber vitamin A yang paling sering dikonsumsi oleh remaja vegan adalah wortel, sayuran hijau seperti bayam, brokoli, kangkung, sawi hijau, dan buah-buahan. Hasil ini sejalan dengan hasil penelitian sebelumnya mengenai asupan zat gizi pada kelompok vegan di Inggris (11) yang menyatakan bahwa kelompok vegan biasanya memiliki asupan vitamin A lebih tinggi dalam bentuk beta-karoten yang berasal dari sayuran hijau dan kuning, serta buah-buahan. Penyerapan beta-karoten akan semakin meningkat jika dalam proses pemasakan bahan makanan nabati sumber vitamin A menggunakan minyak.

Hasil penelitian ini juga menunjukkan asupan harian vitamin $\mathrm{C}$ pada seluruh remaja vegan yang tergolong cukup ( $>65 \%$ dari AKG). Asupan vitamin C yang cukup ini disebabkan remaja vegan mengonsumsi makanan dan minuman yang kaya akan vitamin $\mathrm{C}$ seperti kiwi, jeruk, mangga, jambu air serta beberapa minuman kemasan. Berdasarkan hasil wawancara, para remaja vegan menjelaskan bahwa setiap hari mereka rata-rata mengonsumsi buah-buahan karena mereka merasa bahwa makanan vegan yang memang hanya berasal dari nabati cenderung akan lebih membosankan jika tidak disertai dengan buah-buahan. Hal ini sejalan dengan hasil penelitin pada vegan muda dan nonvegetarian muda di Swedia yang menyatakan bahwa kelompok vegan muda memiliki asupan vitamin $\mathrm{C}$ yang lebih tinggi dibandingkan dengan kelompok nonvegetarian muda (12). Penelitian lain yang dilakukan pada remaja vegetarian dan nonvegetarian di Yayasan Sri Sathya Sai Bali juga menyatakan bahwa rerata asupan vitamin $\mathrm{C}$ pada remaja vegetarian lebih besar dibandingkan dengan remaja nonvegetarian (13). 


\section{Hubungan asupan zat besi dengan kadar Hb pada remaja vegan}

Hasil analisis menunjukkan adanya hubungan yang signifikan antara asupan zat besi dan kadar $\mathrm{Hb}$ pada remaja vegan. Hasil penelitian ini sejalan dengan beberapa penelitian yang serupa. Penelitian pada siswi remaja di MTS Ciwandan Cilegon (14) menyatakan adanya hubungan yang signifikan antara asupan zat besi dengan kadar Hb. Penelitian lain yang dilakukan pada murid sekolah dasar di Kabupaten Bolang Mongondow Utara (15) juga menunjukkan bahwa asupan zat besi berhubungan signifikan dengan kejadian anemia $(p=0,000)$. Hal ini terjadi karena zat besi merupakan komponen utama yang memegang peranan penting dalam pembentukan darah yaitu mensintesis $\mathrm{Hb}$. Asupan zat besi yang kurang dari AKG tidak akan langsung mempengaruhi kadar $\mathrm{Hb}$ karena tubuh masih memiliki cadangan besi di hati, ditambah lagi jika disertai dengan asupan vitamin $\mathrm{C}$ yang cukup akan membantu penyerapan zat besi lebih optimal. Penurunan kadar $\mathrm{Hb}$ terjadi setelah cadangan zat besi habis, yang diawali dengan penurunan kadar feritin (16).

\section{Hubungan asupan vitamin A dengan kadar Hb pada remaja vegan}

Hasil penelitian ini tidak menemukan adanya hubungan yang signifikan antara asupan vitamin A dan kadar $\mathrm{Hb}$ pada remaja vegan. Penelitian mengenai pengaruh vitamin A terhadap kadar $\mathrm{Hb}$ masih belum banyak dilakukan dan memilki hasil yang berbeda-beda. Menurut teori (17), dijelaskan bahwa vitamin A berperan dalam memobilisasi cadangan besi di dalam tubuh untuk dapat mensintesis $\mathrm{Hb}$. Status vitamin A yang buruk berhubungan dengan perubahan metabolisme besi pada kasus kekurangan besi.

Penelitian sebelumnya yang mendukung teori tersebut menyimpulkan bahwa dengan perlakuan suplementasi vitamin A akan meningkatkan kadar $\mathrm{Hb}$, kemungkinan mekanismenya dapat menurunkan anemia karena vitamin A berperan memobilisasi cadangan besi di dalam hati, meningkatkan eritropoiesis, dan mengurangi anemia yang disertai infeksi (18). Tidak adanya hubungan yang signifikan antara asupan vitamin
A dengan kadar $\mathrm{Hb}$ karena optimalnya penyerapan zat besi pada remaja vegan. Optimalnya penyerapan zat besi ini disebabkan oleh asupan vitamin $\mathrm{C}$ pada semua remaja vegan di Pusdiklat Buddhis Maitreyawira yang tergolong cukup dan memenuhi AKG yang dianjurkan sehingga menyebabkan vitamin A tidak perlu menjalankan fungsinya dalam memobilisasi cadangan besi di dalam tubuh untuk dapat mensintesis Hb. Seperti diketahui bahwa vitamin $\mathrm{C}$ meningkatkan penyerapan zat besi di dalam tubuh.

\section{Hubungan asupan vitamin B12 dengan kadar Hb pada remaja vegan}

Penelitian ini menemukan adanya hubungan yang signifikan antara asupan vitamin B12 dan kadar $\mathrm{Hb}$ pada remaja vegan. Hasil ini sejalan dengan penelitian yang dilakukan pada siswi salah satu SMP di Makassar yang menyatakan bahwa ada hubungan yang signifikan antara asupan vitamin B12 dengan kejadian anemia $(\mathrm{p}=0,044)$ (19). Hasil studi pada ibu nifas di Kecamatan Gebog juga menyatakan bahwa ada hubungan yang signifikan antara asupan vitamin B12 dengan kadar $\mathrm{Hb}(\mathrm{p}=0,01)$ (20). Penelitian mengenai hubungan asupan vitamin B12 dan kadar $\mathrm{Hb}$ pada kelompok vegetarian terutama remaja vegan masih sangat sedikit.

Adanya hubungan yang signifikan antara asupan vitamin B12 dengan kadar $\mathrm{Hb}$ pada penelitian ini sejalan dengan peran vitamin B12 yang berfungsi dalam sintesis $\mathrm{Hb}$ dan sel-sel darah merah melalui metabolisme lemak, protein, dan asam folat (21). Vitamin B12 juga berperan sebagai kofaktor dalam pembentukan energi dari protein dan lemak melalui pembentukan succinyl-CoA yang dibutuhkan dalam sintesis $\mathrm{Hb}$ (16). Sebagian besar asupan vitamin B12 pada remaja vegan tergolong kurang, tetapi tubuh hemat dalam penggunaan vitamin B12, yaitu simpanan vitamin B12 dapat bertahan hingga 10 tahun. Oleh karena itu, meskipun asupan vitamin B12 kurang dari kebutuhan, tubuh tetap dapat memenuhi melalui simpanan vitamin B12. Interaksi antara berbagai zat gizi dapat meningkatkan kualitas zat gizi tersebut dalam tubuh sehingga tubuh dapat memanfaatkannya secara optimal. Pemanfaatan zat gizi yang optimal menyebabkan sintesis $\mathrm{Hb}$ dalam tubuh juga berjalan dengan baik. Dengan demikian, meskipun terdapat beberapa asupan zat gizi 
yang kurang tetapi kadar $\mathrm{Hb}$ remaja vegan pada penelitian ini sebagian besar berada dalam kategori normal.

\section{Hubungan asupan vitamin $\mathrm{C}$ dengan kadar Hb pada remaja vegan}

Asupan vitamin C dan kadar Hb remaja vegan pada penelitian ini menunjukkan hubungan yang signifikan. Berdasarkan hasil studi sebelumnya (22) diketahui bahwa adanya hubungan yang signifikan antara asupan vitamin $\mathrm{C}$ dengan kejadian anemia dengan korelasi bernilai positif. Hal ini terjadi karena vitamin C merupakan unsur esensial yang sangat dibutuhkan tubuh untuk pembentukan $\mathrm{Hb}$ terutama pada kondisi tubuh yang kekurangan asupan zat besi. Adanya vitamin $\mathrm{C}$ dalam makanan yang dikonsumsi akan memberikan suasana asam sehingga memudahkan reaksi reduksi zat besi ferri menjadi ferro yang lebih mudah diserap usus halus. Remaja vegan pada penelitian ini hanya mendapat asupan zat besi non-heme. Absorbsi zat besi dalam bentuk non-heme meningkat empat kali apabila tersedia vitamin C. Selain meningkatkan absorbsi zat besi, vitamin $\mathrm{C}$ juga berperan dalam menghambat pembentukan hemosiderin yang sukar dimobilisasi untuk membebaskan besi bila diperlukan. Lebih lanjut, vitamin $\mathrm{C}$ berperan dalam memindahkan besi dari transferin di dalam plasma ke ferritin (6).

\section{Pengaruh asupan $\mathrm{Fe}$, vitamin $\mathrm{A}$, vitamin B12, dan vitamin $\mathrm{C}$ terhadap kadar $\mathrm{Hb}$ remaja vegan}

Berdasarkan hasil analisis multivariat, diperoleh variabel yang berpengaruh terhadap kadar $\mathrm{Hb}$ adalah asupan zat besi $(95 \% \mathrm{CI}=0,005-0,020 ; \mathrm{B}=0,013)$ yang berarti bahwa setiap kenaikan $1 \mathrm{mg}$ asupan zat besi akan menaikkan kadar $\mathrm{Hb}$ sebesar 0,013 g/dl. Sementara itu, hasil analisis untuk asupan vitamin $\mathrm{C}(95 \% \mathrm{CI}=0,001-0,003$; $\mathrm{B}=0,002)$ menunjukkan bahwa setiap kenaikan $1 \mathrm{mg}$ asupan vitamin C akan meningkatkan kadar $\mathrm{Hb}$ sebanyak 0,002 g/dl. Sejalan dengan penelitian pada remaja putri di Semarang (22) yang menyatakan bahwa zat besi dan vitamin $\mathrm{C}$ termasuk dalam faktor yang mempengaruhi kadar $\mathrm{Hb}$. Selain itu, penelitian lain yang dilakukan pada siswi di Cilegon Banten (14) juga menyatakan bahwa zat besi dan vitamin $C$ sebagai faktor yang mempengaruhi kadar $\mathrm{Hb}$. Demikian juga hasil penelitian pada siswi di Makassar yang menemukan bahwa asupan protein, asupan zat besi, asupan vitamin B12, dan asupan vitamin $\mathrm{C}$ memiliki pengaruh terhadap kejadian anemia (19). Hasil penelitian ini juga didukung oleh teori (23) yang menyatakan bahwa remaja putri lebih berisiko menderita anemia daripada remaja putra karena setiap bulan remaja putri mengalami menstruasi. Selain itu, remaja putri sering kali menjaga penampilan sehingga berdiet dan mengurangi makan. Oleh sebab itu, AKG zat besi pada remaja perempuan adalah 19-26 mg setiap hari, angka ini lebih besar jika dibandingkan dengan $\mathrm{AKG}$ zat besi untuk remaja laki-laki yaitu sebesar 13-23 mg setiap hari.

\section{SIMPULAN DAN SARAN}

Hasil penelitian menunjukkan bahwa asupan zat besi, asupan vitamin B12, dan vitamin $\mathrm{C}$ berpengaruh terhadap kadar $\mathrm{Hb}$ remaja vegan. Variabel yang paling mempengaruhi kadar $\mathrm{Hb}$ remaja vegan adalah asupan zat besi dan vitamin C. Berdasarkan hasil penelitian diketahui bahwa asupan zat besi dan asupan vitamin B12 remaja vegan di Pusdiklat Buddhis Maitreyawira masih tergolong kurang sehingga disarankan kepada remaja vegan untuk mengonsumsi suplemen zat besi dan vitamin B12 untuk mengatasi kekurangan asupan zat besi dan vitamin B12 terutama pada remaja yang berjenis kelamin perempuan.

\section{Pernyataan konflik kepentingan}

Penulis menyatakan tidak ada konflik kepentingan dengan pihak-pihak yang terkait dalam penelitian ini.

\section{RUJUKAN}

1. Anggraini, L. Status gizi vegetarian pada komunitas vegetarian di Yogyakarta (kajian pada lactoovo vegetarian dan vegan terhadap status IMT, hemoglobin, feritin, dan protein). Jurnal Gizi Klinik Indonesia 2015;11(4).

2. Craig WJ, Mangels AR. Position of the american dietetic association: vegetarian diets. J Am Diet Assoc 2009;109(7):1266-82.

3. Abdulla M, Andersson I, Georg N, Berthelsen K, Birkhed D, Ockerman PA, et al. Nutrient intake and health status of vegans: chemical analyses of diets 
using the duplicate portion sampling technique. Am J Clin Nutr 1981;34(11):2464-77.

4. Nugroho F, Handayani D, Apriyani Y. Asupan protein nabati dan kejadian anemia wanita usia subur vegan. J Gizi Pangan 2015;10(3):165-70.

5. Farida, Ida. Determinan kejadian anemia pada remaja putri di Kecamatan Gebog Kabupaten Kudus Tahun 2006 [Tesis]. Semarang: Universitas Diponegoro; 2006.

6. Almatsier, S. Prinsip dasar ilmu gizi. Jakarta: Gramedia Pustaka Utama; 2009.

7. Webster-Gandy J, Madden A, Holdsworth M. Gizi \& dietetika. Jakarta: Penerbit Buku Kedokteran EGC; 2014.

8. Almatsier S, Soetardjo S, Soekatri M. Gizi seimbang dalam daur kehidupan. Jakarta: Gramedia Pustaka Utama; 2011.

9. Stark R, Miller AS. Gender and religiousness: can socialization explanations be saved?. AJS 2002;107(6):1399-423.

10. Notoatmodjo S. Promosi kesehatan dan ilmu perilaku. Jakarta: Rineka Cipta; 2007.

11. Philips F. Vegetarian nutrition. London UK: British Nutrition Foundation; 2005.

12. Larsson CL. Dietary intake and nutritional status of young vegans and omnivores in Sweden. Am J Clin Nutr 2002;76(1):100-6.

13. Nai HME. Kecukupan asupan gizi remaja vegetarian dan nonvegetarian di Yayasan Sri Sathya Sai Bali Tahun 2011. Arc Com Health 2012;1(1):43-9.

14. Pratiwi E. Faktor-faktor yang mempengaruhi anemia pada siswi remaja di MTS Ciwandan Cilegon
Baten Tahun 2015 [Tesis]. Jakarta: UIN Syarif Hidayatullah; 2015.

15. Arifin SU. Hubungan asupan zat gizi dengan kejadian anemia pada anak sekolah dasar di Kabupaten Bolaang Mongondow Utara. eJournal Keperawatan 2013;1(1).

16. Gibson RS. Principles of nutritional assessment $2^{\text {nd }}$ Ed. New York: Oxford University Press Inc; 2005.

17. Gillespie S. Major issues in the control of iron deficiency the micronutrient initiative. New York: UNICEF; 1998.

18. Palafox NA, Gamble MV, Dancheck B, Ricks MO, Briand K, Semba RD. Vitamin A deficiency, iron deficiency and anemia deficiency among preschool children in The Republic of The Marshall Islands. Nutrition 2003;19(5):405-8.

19. Syatriani S. Konsumsi makanan dan kejadian anemia pada siswi salah satu SMP di Makassar. Jurnal Kesehatan Masyarakat Nasional 2010;4(6):251-4.

20. Saputri TI. Perbedaan asupan protein, zat besi, asam folat, Vitamin B12 dan kejadian anemia pada ibu nifas yang melakukan mutih dan tidak melakukan mutih di Kecamatan Gebog Kabupaten Kudus [Tesis]. Semarang: Fakultas Kedokteran Universitas Diponegoro; 2015.

21. Wardlaw G. Contemporary nutrition issues and insights. Toronto: Mosby Year Book; 1992.

22. Kirana DP. Hubungan asupan zat gizi dan pola menstruasi dengan kejadian anemia pada remaja putri di SMA N 2 Semarang [Artikel penelitian]. Semarang: Universitas Diponegoro; 2011.

23. Adriani MSM. Peranan gizi dalam siklus kehidupan. Jakarta: Kencana; 2012. 